\title{
EL INFORME CONTRA IDOLORUM CULTORES DEL OBISPADO DE YUCATÁN
}

\author{
RUTH GUBLER \\ University of California, Los Ángeles
}

La obra de Pedro Sánchez de Aguilar, Informe contra idolorum cultores del obispado de Yucatán (1987), redactada en 1613 pero impresa hasta 1639, es una fuente excelente para juzgar el clima religioso que imperaba durante la época. ${ }^{1}$ En ella el autor reflexiona sobre dos de las mayores preocupaciones del momento: 1) lo que se consideraba un rebrote de "idolatría", ${ }^{2}$ obsesión compartida en otras áreas del Nuevo Mundo, de lo cual dan fe documentos testimoniales de las mismas; y 2) la disputa entre el brazo civil y el eclesiástico con respecto a la competencia (exclusiva) del obispo para juzgar y castigar a los indios "idólatras".

Desde un principio, fueron una característica del periodo posterior a la Conquista los frecuentes conflictos entre los diversos grupos de españoles que habían llegado al Nuevo Mundo, debido tanto a los motivos que los habían llevado allá como, posteriormente, a la defensa de sus propios intereses creados: confrontaciones entre conquistadores, colonos, encomenderos, oficiales del rey (y todos ellos en algún momento en conflicto con los religiosos).

Las alineaciones en un bando u otro variaban dependiendo de las circunstancias y de los intereses creados afectados. En ocasiones eran los encomenderos quienes estaban en conflicto con los frailes; otras veces, los últimos estaban enfrentados con los oficiales del rey, o éstos con los encomenderos. La única constante en estas controversias era que los indios siempre llevaban la peor parte.

Dentro de la misma Iglesia también se manifestaban rivalidades y desacuerdos, bien dentro de la misma orden o bien entre una y otra; por ejemplo, entre los franciscanos y dominicos, ${ }^{3}$ entre éstos y el clero secular o el episcopado. Muchos

\footnotetext{
${ }^{1}$ El estudio se refiere a los años comprendidos aproximadamente entre 1560 y 1660 , es decir, a un proceso que se venía arrastrando desde el comienzo de la labor misional y que se fue desarrollando durante los subsecuentes decenios.

${ }^{2}$ A pesar de reflejar la actitud etnocéntrica no sólo de los religiosos sino también del catolicismo como religión institucionalizada, este término se sigue utilizando entre los académicos para encapsular en una sola palabra todo un concepto relativo a creencias que no compaginaban con el cristianismo (tanto prehispánicas como de otras áreas del mundo). Aquí se escribe entre comillas para indicar la conciencia de ese prejuicio etnocéntrico.

${ }^{3}$ En Yucatán éstas no se manifestarían hasta las postrimerías del siglo xvı, pues hasta entonces los franciscanos fueron los únicos que misionaban en la península. Sin embargo, al morir Toral se asignó a un dominico como obispo de la península: fray Gregorio de Montalvo (1580-1587).
} 
de los conflictos se centraban en la competencia de cada cual, la administración de los indios, el derecho a su trabajo, la adjudicación de doctrinas, etcétera.

De acuerdo con la constitución jerárquica de la Iglesia, sus actividades organizadas normalmente habían de caer bajo el control y la dirección de los obispos (Boxer, 1978: 65); pero no siendo posible en un principio, en 1522 el papado otorgó a los superiores de las órdenes religiosas la autoridad omnímoda para la conversión y administración parroquial (id. 66), así como extensos privilegios en gran parte exentos del control y dirección del episcopado. Ello daría pie a futuras confrontaciones y luchas de poder.

Como apunta Ricard (1947), si durante los primeros años tras la Conquista había existido una estrecha cooperación entre los religiosos, debido a la escasez de misioneros, esta situación fue cambiando en la medida en que fue aumentando su número, haciéndose cada vez más compleja la organización y jerarquía eclesiásticas. Además, entre 1560 y 1580 hubo dentro de la orden franciscana una especie de escisión debido a motivos políticos, a desacuerdos entre criollos y peninsulares, y a una polarización entre quienes favorecían métodos más benignos con los indios y otros que insistían en proceder con mano dura (Phelan, 1970: 57). "Comenzaron entonces la divergencias de opinión, la oposición de modos de ver las cosas, o de temperamentos naturales, la incompatibilidad de caracteres, la rivalidad de personas, las abiertas rivalidades hostiles [...]" (Ricard, 1947: 424).

Volvamos al caso específico de la disputa entre los oficiales del rey y los obispos sobre el derecho de aprehender y castigar a los indios "idólatras". En las siguientes páginas examinaremos los fundamentos en los que se basaba Sánchez de Aguilar para argumentar que estos asuntos, relativos a la salud espiritual de los indios, tan sólo incumbían a las autoridades eclesiásticas, sin necesitar de la intervención del brazo civil. Para apoyar sus argumentos, Sánchez de Aguilar llama a su favor los escritos de autoridades eclesiásticas, y por medio de razonamientos lógicos y persuasivos logra convencer de que en efecto este privilegio le correspondía a la Iglesia.

\section{Datos biográficos}

La obra de Sánchez de Aguilar refleja la vida y el modo de pensar del autor, y éste, por su familiaridad con el área y su gente, por su conocimiento del idioma maya, así como por su larga carrera eclesiástica, estaba eminentemente calificado para opinar sobre el tema.

Nacido en Valladolid el 10 de abril de 1555, Sánchez de Aguilar era nieto del conquistador Fernando de Aguilar, uno de los primeros doce regidores de Mérida, y hermano de dos encomenderos, don Alonso y don Francisco de Aguilar. ${ }^{4}$ Estudió

\footnotetext{
${ }^{4}$ Datos de las notas bibliográficas de Francisco Cantón Rosado en la edición de 1937 del Informe contra idolorum cultores (páginas I-IV).
} 
la gramática maya con Gaspar Antonio Xiu, recibiendo su primera instrucción en Tizimín entre 1562-1565 (Rosado 1937: I-II; también Yucatán en el tiempo 1998, tomo 5: 412). ${ }^{5}$ Después fue enviado a la Ciudad de México y educado en el Colegio de San Ildefonso, donde se ordenó presbítero y continuó sus estudios hasta obtener el doctorado en la Real y Pontificia Universidad. Regresó a Yucatán y fue nombrado cura de la parroquia de Calotmul, Chancerote (1595), Valladolid (1596) ${ }^{6}$ y Tizimín.

Sánchez de Aguilar pasó luego a Mérida y fue adscrito al sagrario de la catedral de Mérida. En 1602, en forma interina, fungió como provisor y vicario general de Yucatán. En 1613 fue designado deán de la catedral, año en que comenzó su obra Informe contra idolorum cultores... En 1617 fue llamado a Madrid como procurador de la provincia de Yucatán, momento que aprovechó para llevar consigo su obra a España (donde finalmente fue impresa en la capital del reino en 1639). Posteriormente, en 1619 fue nombrado canónigo de la catedral metropolitana de la ciudad de La Plata en la provincia de Las Charcas. Hizo un breve viaje a Yucatán para despedirse de su familia y pasó a ocupar su cargo, que desempeñó por muchos años. ${ }^{7}$

Evidentemente, por un lado su ascendencia y por otro su educación como eclesiástico creaban una interesante combinación de intereses. En cuanto a la primera, es clara su defensa de los intereses creados y del status quo de los españoles frente al de los indígenas, muy en particular en lo que se refiere a los derechos de la conquista. Como clérigo, su postura en la disputa contra el Estado acerca de la competencia para juzgar y castigar casos de idolatría es la de una vigorosa defensa de la primacía de la Santa Madre Iglesia.

Muchas de las preocupaciones y actitudes expresadas en el Informe, el cual se centra en la difícil empresa de extirpar las antiguas prácticas idolátricas en la península de Yucatán, encuentran eco en varias fuentes de otras áreas del Nuevo Mundo, tanto del siglo XVI como del XVII: del altiplano de México en las obras de Durán (1576-1579), Sahagún (ca. 1579), Mendieta (1596) y otros; de Oaxaca en las de Balsalobre (1654) y De la Serna (1656); en la de Ruíz de Alarcón (1629) de Atenango, Guerrero, como también del Perú en las obras de Acosta (1588) y Arriaga (1621), principalmente.

\section{El problema de la idolatría}

Desde el principio de la tarea misional, la idolatría fue una constante preocupación de la Iglesia, y por lo tanto también de la Corona, al constatar cuán arrai-

\footnotetext{
${ }^{5}$ Éstos y los siguientes datos biográficos fueron extraídos de las dos fuentes anteriormente mencionadas.

${ }^{6}$ Aquí escribió Memoria de los primeros conquistadores, Catecismo cristiano en lengua maya y Catálogo de las deidades mayas, todas obras perdidas.

${ }^{7}$ Se fecha su muerte alrededor de 1648.
} 
gadas estaban las antiguas creencias y cuán difíciles eran de erradicar. ${ }^{8}$ A pesar de toda la vigilancia y el cuidado de los frailes, los indios seguían aferrados a sus antiguos dioses y prácticas religiosas, resultado tanto del apego que tenían a sus tradiciones como de la superficialidad de su conversión. Si bien se podía imponer el cumplimiento exterior de los requisitos de la fe, tal como lo mandaba la Iglesia, no se podía mandar en un nivel afectivo. Complicaba el problema el hecho de que los indios mezclaban elementos cristianos con viejas prácticas autóctonas o escondían y veneraban a sus propias deidades bajo el altar de la iglesia, mientras aparentaban cumplir con sus deberes cristianos. También seguían realizando sus ceremonias y sacrificios dentro de cuevas y milpas y bebiendo la bebida ceremonial, balché, ${ }^{9}$ cuya elaboración se había prohibido (Cédula contra el pulque, ques lo propio que balche, 24 de agosto de 1529). ${ }^{10}$

Era una continua pugna entre la latría ${ }^{11}$ — la verdadera religión- (Bernard y Gruzinski 1992: 42) y la idolatría. Como lamenta Lizana (1633) en su prólogo al Devocionario de Nuestra Señora de Izamal (1995: XIII): "[los indios] en lugar de alabar a su Criador y Redemptor Christo, dauan continuas alabanzas al Demonio, su capital asolador y destruidor de sus almas. Assí como deuían ofrecer los corazones puros y limpios a su Dios y Criador, le ofrecían los corazones, con la sangre envueltos de los sacrificados, al Demonio [...]".

A pesar de las campañas llevadas a cabo para destruir los antiguos asentamientos religiosos, de las que nos informa en fecha muy temprana (1533) fray Martín de Valencia, ${ }^{12}$ y la destrucción de imágenes, códices y otros elementos religiosos, además de la constante predicación y supervisión de los indígenas y el empleo del castigo, persistían las antiguas creencias y costumbres. Los frailes son unánimes en sus quejas al respecto, lamentando el gran número de dioses en el panteón indígena y la persistencia de los indios en adorarlos (Acosta 1952,

\footnotetext{
${ }^{8}$ La lucha contra la idolatría y las campañas de extirpación constituyeron los aspectos más relevantes de la labor misional.

${ }^{9}$ El Diccionario maya Cordemex (1980: 34) lo define como "árbol cuya corteza sirve para preparar la bebida así llamada, echándola en remojo en aguamiel para su fermentación".

${ }^{10}$ Sánchez de Aguilar (1987: 37); Cedulario de Puga (1878, tomo I: 143-144, foja 70). Véase también el artículo de Chuchiak (2003: 137-171) sobre el balché y el uso ritual de las bebidas intoxicantes.

${ }^{11}$ La latría y la idolatría se explican tomando como base las ideas de Las Casas y la herencia escolástica de acuerdo con la cual el alma tiene tres virtudes o potencias naturales (la racional, la concupiscible y la irascible). Si la razón encuentra la verdad primera, que es el conocimiento del verdadero Dios, las otras dos la reforzarán, resultando en latría. Si por el contrario, debido a la ignorancia del ser humano y a la corrupción de su naturaleza, la razón se dirige a "una falsa transferencia", tendrá como consecuencia que las tres potencias se desvíen de su curso, cayendo el hombre en el error de la "idolatría". Entonces "el hombre empieza a adorar cosas en las que reconoce un "signo o una apariencia de bondad", es decir, los ídolos, o bien se rebaja a rendir culto a los seres representados [por ellos]" (Bernard y Gruzinsk, 1992: 42).

12 “...nos repartimos por las provincias mas populosas derribando innumerables cues y templos donde reverenciaban sus vanos idolos y hazian sacrificios humanos sin cuenta y les posimos en su lugar cruces, y comenzamos a edificar iglesias, y monesterios para les comunicar la doctrina cristiana y el santo baptismo ..." (Códice franciscano 1941: 162).
} 
Durán 1995, Landa 1986, Mendieta 1980, Motolinía 1988, Sahagún 1981 y otros en el siglo xvi; y más tarde, en el xvII, Ruiz de Alarcón 1987, Balsalobre 1987, López de Cogolludo 1971, De la Serna 1987, y el propio Sánchez de Aguilar, etcétera).

Nuestra información más temprana sobre la conversión de los indígenas del Nuevo Mundo proviene del Altiplano de México, antecediendo la experiencia en Yucatán, donde la labor misionera comenzó aproximadamente entre 1534 y $1535 .{ }^{13}$ Las obras de Sahagún ${ }^{14}$ y Durán ${ }^{15}$ son particularmente ricas en información referente a las dificultades y problemas que enfrentaban los religiosos en la conversión y la erradicación de la idolatría, proporcionando además un amplio acopio de detalles sobre el mundo indígena. También son de gran utilidad fuentes más tardías como Balsalobre (1654), De la Serna (1656) y Ruiz de Alarcón (1629). ${ }^{16}$ De la Serna es de nuestro particular interés, pues coincide con muchos de los puntos de vista de Sánchez de Aguilar, cuya obra examinamos aquí.

Las fuentes mencionadas vienen a llenar de cierto modo la escasez de datos sobre Yucatán, ya que (salvo Landa, quien le dedicó toda una obra Relación de las cosas de Yucatán [ca.1560]) ni Lizana (1633), ni López de Cogolludo (1656), ni el mismo Sánchez de Aguilar nos proporcionan muchos datos acerca de la historia y la cultura indígenas. En Lizana la información de esta naturaleza se limita al libro 1, parte primera, capítulos I-V (1995: 57-66) y capítulos X-XII (ibid.: 78-88), y en el libro 2, a los capítulos II y III (ibid.: 139-142); en López de Cogolludo a los capítulos III-IX del libro IV (232-261); y en Sánchez de Aguilar hay una corta sección sobre "abusiones" de los indios (1987:83-84) y "Costumbres de los de Yucatán en su gentilidad" (ibid.: 94-99). En todo caso, los datos son escuetos, tomando en cuenta el total de las páginas restantes de sus obras, dedicadas a describir la conquista y la labor evangélica y a loas de la vida y obras de los frailes.

Si como explicación de la falta de fuentes yucatecas con énfasis etnográfico nos apoyamos en la explícita cédula real de Felipe II, dictada el 22 de abril de 1577 en Madrid y que prohibía escribir sobre las antiguas prácticas (“idolatría”) y creencias ("supersticiones"), esto no aclara por qué, comparándolas siglo por siglo con las fuentes del Altiplano y del Perú, es tan marcada la pobreza de información en las primeras mientras hay un gran acopio de datos en las últimas. Visto de otra forma, como los frailes al misionar en Yucatán no dejaron enteramente a un lado el tema, sino lo trataron en forma tan sumaria, podría tratarse de una falta de interés.

\footnotetext{
${ }^{13}$ Las fuentes discrepan al respecto.

${ }^{14}$ Véase su Historia general de las cosas de Nueva España escrita ca. 1579.

${ }^{15}$ Véase su Historia de las Indias de Nueva España e islas de Tierra Firme (ca. 1576-1579).

${ }^{16}$ Véase su "Tratado de las supersticiones y costumbres gentílicas que oy viven entre los indios naturales de desta Nueva España”. Al igual que Sánchez de Aguilar, Ruiz de Alarcón fue juez comisionado por el juzgado eclesiástico de su obispado para la averiguación y el castigo de idolatrías, así como de la ejecución de los procesos.
} 
Otra posible explicación es el número de obras yucatecas dadas como perdidas (Tozzer, 1977: 151-153) y la posibilidad de haber existido entre ellas alguna fuente que informara al respecto. Sin embargo, tomando en cuenta los títulos listados por Tozzer, ello no parece posible. Por el contrario, evidencian que los frailes durante su labor misional en Yucatán en el siglo xvi escribieron mayormente artes o vocabularios o doctrinas (Villalpando, Landa, Ciudad Real y Torralva); sermones (Solana, Ciudad Real y Torralva), y alguna que otra relación (Xiu y Nájera). Posteriormente el énfasis recae de nuevo sobre vocabularios, diccionarios, sermones, y alguna que otra doctrina o confesionario. La excepción para el siglo xvı es Solana, cuyos apuntes históricos, de acuerdo con el título, podrían haber informado sobre las costumbres indígenas y, por lo tanto, quizá sobre los esfuerzos de los frailes para erradicarlas; desafortunadamente no lo sabremos nunca pues están perdidas.

Lo anterior nos lleva a preguntarnos si el enfoque de los frailes en Yucatán no habrá sido diferente al de los religiosos en México o el Perú, o si en efecto no compartían los mismos intereses etnológicos. De los primeros, sólo Landa, en su “exilio involuntario" en España, rememoraba la tierra que debió dejar atrás.

Además, si se prohibía escribir sobre algunos aspectos de la cultura indígena, esto no aclara por qué los frailes no dejaron escritos más detallados sobre su labor misional y sus esfuerzos por combatir la idolatría, o sobre sus campañas de extirpación (como lo hicieron los otros), pues esta tarea tenía una alta prioridad y seguramente detalles al respecto hubieran sido del agrado de las autoridades tanto civiles como eclesiásticas. Es notable la poca atención que le prestan frailes como Lizana y Cogolludo y aun Sánchez de Aguilar quien, si bien se explaya en el tema de la idolatría, es para arremeter contra ella verbalmente, anotar algunos ejemplos de la destrucción de ídolos, acción en que también estuvo involucrado, y finalmente para dejarnos su obra. Estos frailes no se detienen en informar detalladamente sobre la labor misional en Yucatán, salvo cuando comentan la audacia, valentía y espíritu de sacrificio de los primeros misioneros, o cuando describen hechos heroicos individuales como el de fray Luis de Villalpando y Melchor de Benavente, a quienes los indios tramaron quemar vivos con casas e iglesia, o cuando Landa enfrentó a los indígenas a punto de sacrificar a un joven. Para lo demás se quedan cortos a la hora de evaluar el proceso, las dificultades y los constantes problemas de la conversión, ${ }^{17}$ de lo cual las fuentes del Altiplano nos informan ampliamente.

Después de esta digresión, volvamos a los autores del Altiplano y a sus lamentaciones sobre la idolatría. Al mencionar la persistencia de las antiguas creencias entre los mexicas, Sahagún (1981: 27) advierte: "Los pecados de la idolatría y ritos idolátricos y supersticiones idolátricas y aguieros, y abusiones

17 Véase por ejemplo la sumaria mención del auto de fe de Maní, hecho históricamente tan importante que bien merecía un trato exhaustivo. Sin embargo, López de Cogollado le dedica apenas dos párrafos y Lizana aun menos, sólo unas pocas frases. 
y ceremonias idolátricas, no son aun perdidos del todo”. Durán (1995: 16) concuerda, apuntando: "en todo se alla superstición y idolatría; en el sembrar, en el coger, en el encerrar en las troxes, asta en el labrar la tierra y edificar las cassas; y pues en los mortorios y entierros y en los cassamientos y en los nacimientos de los niños [...] finalmente, en todo mezclaban superstición y idolatría [...]". Cita la observancia de los buenos y malos signos en "tratos y contratos y vender, en casamientos, en baños, en comer tales y tales comidas [...]", etc. (ibid.: 232); la costumbre de poner junto con el nombre cristiano el del antiguo signo bajo el que la criatura nació (ibid.: 242) o de pedir cierto día para solemnizar una fiesta, intentando juntar la fiesta cristiana con la de alguno de sus antiguos dioses (ibid.), o de colgar en los techos manojos de mazorcas (ibid.: 248-249).

Sospecho con vehemente sospecha que debe de haber quedado un olorcillo de alguna superstición en algunos que tienen gran afinidad con idolatrías y que no faltan el dia de hoy algunos viejos y los ha habido domatizadores agoreros doctos en su vieja ley que han enseñado y enseñan á los mozos que agora se crian enseñándoles la cuenta de los dias de los años y las cerimonias y ritos antiguos los fabulosos y engañosos milagros y mandatos que de los Dioses tenian [...] (ibid.: 224).

Al ver cómo se guardaban "inviolablemente" (ibid.: 232) las viejas tradiciones, expresa su temor de que en efecto éstas no se hayan podido desarraigar.

Ambos frailes llaman la atención sobre el hecho de que muchos religiosos no le daban suficiente importancia a la evidencia de antiguas prácticas o no las reconocían como una forma sutil de idolatría. Dice Durán (1995: 86):

Tengo por inconveniente el çufrillo y disimulallo y asi cunplo con dar el avisso: remedielo el que se sintiere con obligaçión y no encargue su conçiençia disimulando y consintiendo estas y otras supesticiones y teniendolas por cossas minimas y que no ban ni bienen y no riñendolas y reprendiendolas mostrando enojo y pesadumbre dellas bienen los yndios a encaminarse y a cometer otras cossas pessadas y graves remaneciendo ydolatras después de muchos años de dotrina [...].

Sahagún (1981: 27) compara al religioso con el médico, quien necesita saber la causa de la enfermedad para poder aplicar la medicina; así también el primero debe saber reconocer la idolatría para poder tomar las medidas necesarias para combatirla: "que por falta de no saber esto en nuestra presencia hacen muchas cosas idolátricas, sin que lo entendamos; y dicen algunos, excusándolos, que son boberías y niñerías, por ignorar la raíz de donde salen que es mera idolatría [...]".

Estos temas siguen siendo motivo de constante preocupación durante los próximos decenios, y a mediados del siglo xvII (1656) De la Serna informa que 
poco ha cambiado: "siguen los cultos, y ceremonias de sus antepasados; inclinación, que está embebida en su misma sangre para la propensión á la idolatria, y superstición [...]" (1987: 449). Repite la misma queja sobre los ministros que no daban suficiente importancia ni reconocían la gravedad del caso:

Por estos sucesos vistos con los ojos, y tocados con las manos, nos abran el entendimiento, para acabar de persuadirnos, á que es verdad, que ay idolatrias en todas partes, y que tienen estos indios muchas supersticiones, y abusos contrarios á nuestra Sancta fée, pues es muy cierto, que generalmente hablando, muchos Ministros no lo quieren creen, y quando se lo dicen, lo tienen á cosa de poco fundamento, y demassiada ignorancia de indios; siendo assí que son cosas gravísimas [...] (De la Serna 1987: 311-312).

Expresa el mismo temor de Durán: si la predicación y enseñanza de los ministros no logra acabar con estas costumbres, va a ser difícil erradicarlas (ibid.: 458). Por ello insiste en que "el principal remedio de estas idolatrias y supersticiones y del que mas continuamente se á de usar [...] es la predicación de los Ministros Evangelicos, encaminando en ella su doctrina á desengañar estos miserables ilusos, dandoles á entender y conocer la pureza de Nuestra Sancta Fée [...]" (ibid.: 457).

En general, el sistema religioso mesoamericano era de carácter abierto o inclusivo; permitía la incorporación de otros dioses en su panteón, conformado por numerosas deidades. Aunque las fuentes etnohistóricas yucatecas no son tan explícitas al respecto como las de la cuenca de México, ${ }^{18}$ debe haber existido como constante esta misma cualidad, ya que se extendía aun hasta la América del Sur. Por ejemplo, aunque los incas exigían a los pueblos conquistados venerar a su deidad principal, el Sol, mandando edificar suntuosos templos en su honor (Cieza de León, 1959), no impedían a los derrotados seguir adorando a sus propios dioses.

Jacinto de la Serna describe esta tolerancia religiosa (si así la podemos llamar):

tenian por costumbre [...] que quando venia alguna nacion á poblar de nuevo entre la que yá estaba poblada; los unos recevian por Dios á el que traian los que venian de nuevo, y éstos en recompensa veneraban por su Dios á el que tenian los ya poblados [...] y assí se fueron multiplicando los Dioses según la multiplicidad de las naciones, que estaban, y iban viniendo de nuevo, reciviendo los unos los dioses de los otros, y al contrario [...]" (De la Serna, 1987: 280).

Quizá el autor tuviera razón en aseverar que esto obraba a favor de los misioneros y que: "por esta razón se inclinaron tan facilmente estos indios

\footnotetext{
${ }^{18}$ Por lo mismo, y porque son tanto más explícitas las fuentes mexicanas al respecto, acudimos a ellas para ejemplificar muchos de los problemas relacionados con la idolatría, generalizada en todo el Nuevo Mundo.
} 
á recevir por Dios á Christo Señor Nuestro por medio de los Españoles [...]" (De la Serna, 1987: 280). Sin embargo, si este hecho facilitaba la inclusión de un nuevo dios en el panteón, a la vez reforzaba el otro aspecto, la costumbre de no olvidar a las deidades propias, venerándose simultáneamente a unas y a otras. Resume diciendo De la Serna que: "pareciendo verdaderos cristianos, no lo son, y siendo idolatras formales se ocultan de manera, que son verdaderos hipócritas pretendiendo engañar sus Ministros" (ibid.: 449).

Pero la base del cristianismo es su exclusivismo; como lo dice claramente el primer mandamiento: no se ha de tener otros dioses más que un solo, único, Dios. Por lo tanto, era necesario hacerle entender a los indios "la pureza de Nuestra Sancta Feé, que no admite mezcla de otros Dioses, ni mezcla de errores, y supersticiones contra sus catholicas verdades [...]" (De la Serna, 1987:457). Sin embargo, precisamente allí radicaba la dificultad de la conversión. Aunque, como se ha dicho, los indios no eran renuentes a aceptar a otros dioses, no estaban dispuestos a abandonar a los propios, y citamos un bello ejemplo del razonamiento que hicieron los principales mexicas en los Coloquios de los Doce ([1524]; León-Portilla, 1986: 151):

Decían [nuestros progenitores]:

Que ellos, los dioses, son por quien se vive, que ellos nos merecieron.

¿Cómo?, ¿dónde? Cuando era aún de noche.

Y decían [nuestros ancestros]:

Que ellos [los dioses] nos dan

nuestro sustento, nuestro alimento,

todo cuanto se bebe, se come $[\ldots]$

Ellos son a quienes pedimos

el agua, la lluvia,

por las que se producen las cosas en la tierra.

[...]

Y ahora, nosotros,

¿destruiremos

la antigua regla de vida? [...]

Señores nuestros,

no hagáis algo

a vuestra cola, vuestra ala,

que le acarree desgracia,

que la haga perecer [...]

Y no sea que, por esto, ante nosotros,

se levante la cola, el ala [el pueblo],

que no sea que, por ello, nos alborotemos,

no sea que desatinemos [...] (ibid.: 151-153). 
López de Cogolludo (1971, libro I, capítulo VI: 25) registra una reacción similar de parte de los mayas cuando Cortés exigió a los sacerdotes y caciques de Cozumel que reemplazaran las figuras de sus dioses con una imagen de la Virgen. Éstos le respondieron:

Que sus mayores, de quien descendían, por muchas edades habían adorado aquellos Dioses, a quien ellos tambien reverenciaban y tenian por buenos; de quien recibian los bienes, y salud que tenian, y que así no se atreverian á quitarlos de alli, ni dejar su adoracion, porque perderian sus sementeras y lo demás, que de ellos recibían y que enojados se les huirian á la mar y los perderian [...].

Este estado de cosas no habría de cambiar apreciablemente con el paso de los años, manteniéndose vivas las antiguas tradiciones pues los indios, por autopreservación, trataban de llevarlas a cabo subrepticiamente. Las costumbres y creencias no se erradican tan fácilmente y más de un siglo después (1656) Jacinto de la Serna (1987: 279-280) habría de escribir que:

tienen por tan necessarias sus supersticiones, é idolatrias, que sin ellas no les sucederá ninguna cosa bien [...] y hazen tanta fuerça en esta tradición, que viene de Padres á Hijos, que muestran gran sentimiento quando ven, que se vá olvidando y dicen: [...] Pues cómo? áse de olvidar, y perder lo que nos dexaron enseñado los viejos antiguos?...

Bien se echa de ver por todo esto, como en aquel tiempo no estaban olvidados los Indios de sus idolatrias, y de sus idolos, como se pensaba; pues ellos tenian tanta confiança, que aunque creen, que ay Dios; pero tambien tienen por cierto, que les vienen las cosas temporales por mano de sus idolos; y assi se las piden como si estuviesen en su mano, y por esso les hazen reverencia, y los temen mas que a el verdadero Dios... (ibid.: 283).

A pesar de su aparente cumplimiento exterior con la nueva fe, los indígenas seguían fieles a sus antiguos dioses. Se informó a los frailes la costumbre de esconder sus bultos en las mismas iglesias o en los pies de las cruces o en las gradas debajo de las piedras "para allí hacer que adoraban la cruz y adorar al demonio, y querían allí guarecer la vida de su idolatría" (Motolinía, 1988: 73). Sigue diciendo el mismo autor que los frailes vieron cómo "tenían algunas imágenes con sus altares, junto con sus demonios e ídolos; y en otras partes la imagen patente y el ídolo escondido, o detrás de un paramento, otras la pared, o dentro del altar [...]" (ibid.: 67-68), indicación de que bajo la veneración (verdadera o fingida) de las imágenes católicas simultáneamente estaban adorando a sus antiguas deidades. Las imágenes de la Virgen María y de Cristo se habían colocado entre los ídolos, venerándose ambos a la par. Por ello especulaba Motolinía: o bien se los habían dado los cristianos pensando que sólo a ellos los iban a adorar o que los indios "como tenían cien dioses, querían tener ciento y uno [...]" (ibid.: 67). 
Un siglo más tarde, De la Serna habría de reflexionar sobre la persistencia de estas prácticas y la fingida observancia del ritual cristiano, apuntando:

Y para mejor dissimular su engaño, y ponçoña, la doran, mezclando sus ritos, y ceremonias idolatricas con cosas buenas, y sanctas, juntando la luz con las tinieblas á Christo con belial, reverenciando á Christo Señor Nuestro, y á su sanctissima Madre, y á los sanctos (á quienes algunos tienen por Dioses) venerando juntamente á sus idolos" (1987: 281). ${ }^{19}$

Aunque a todas luces el siglo xvi había concluido con el sometimiento y la aparente cristianización de los indígenas, la idolatría seguía latente y muy a menudo se desarrollaba clandestinamente. Y si en un momento Mendieta llegó a aseverar cómo: "con ser tan nuevos en la fe, que algunos de ellos se hallaron en sus pasadas idolatrías, el tiempo de ahora no se siente más rastro dellas (á lo menos adonde alcanzan suficiente doctrina)" (Códice Mendieta 1971, tomo II: 33), se equivocaba. Quizá la incipiente euforia de los religiosos se debía a que estaban cegados por el gran número de conversos a los cuales se refieren Mendieta y otros; ${ }^{20}$ o como lo indican Sahagún y Durán, a menudo no reconocían la evidencia de la práctica de antiguos ritos idolátricos aún si a veces era ante sus mismos ojos.

Sin embargo, posteriormente lloverían las quejas al respecto. El mismo Mendieta (1980, libro III, capítulo XXIII: 232) habría de reconocer que no se podía cantar victoria, lamentando: "Ya que pensaban los religiosos que con estar quitada la idolatria de los templos del demonio y venir algunos a la doctrina y baptismo, estaba todo hecho, hallaron que era mucho más lo que quedaba por hacer y vencer." 21

Para hacer frente a este "rebrote de idolatría", los religiosos decidieron valerse de los métodos sancionados por el Santo Oficio de la Inquisición, implementando procesos inquisitoriales en varias partes del Nuevo Mundo: en la Nueva España bajo el obispado de Juan de Zumárraga entre 1536 y 1543, en Oaxaca bajo el de Tello de Sandoval entre 1544 y 1547 y en Yucatán gracias a Diego de Landa en el famoso proceso conocido como el auto de fe de Maní en 1562.

La Inquisición española fue instituida a fines del siglo $\mathrm{xv}^{22}$ y se implantó exclusivamente en España ${ }^{23}$ y en las colonias españolas, donde conservaba todos

\footnotetext{
${ }^{19}$ Lamentaciones al respecto abundan en las obras de Acosta (1952), Durán (1995), Motolinía (1988), Sahagún (1981), De la Serna (1987), y por supuesto Sánchez de Aguilar, a quien estudiamos aquí.

20 También Motolinía (1988) y Torquemada (1975-1979).

${ }^{21}$ Estas palabras se encuentran verbatim en Motolinía (1988: 72), salvo que añade: "hallaron lo más dificultoso y que más tiempo fue menester para destruir, y fue que de noche se ayuntaban, y llamaban y hacían fiestas al demonio, con muchos y diversos ritos que tenían antiguos [...]”.

${ }^{22}$ Le precedía la inquisición medieval, instituida en el siglo xill y que duró hasta el xv.

${ }^{23}$ Allí se había establecido la Inquisición como institución político-religiosa bajo el reinado de los Reyes Católicos con el fin de controlar elementos potencialmente peligrosos, como los moris-
} 
los aspectos de su contraparte española. En el Nuevo Mundo se instauró en dos virreinatos, el de la Nueva España y el del Perú. En el primero estaban incluidos el arzobispado de México y los obispados de Nueva Galicia, Michoacán, Tlaxcala, Yucatán, Oaxaca, Chiapas, Veracruz, Guatemala, Honduras y Nicaragua. Con ello se afirmaba la supremacía del poder divino sobre el temporal: Dios estaba por encima del Estado, de la sociedad y del individuo (Mariel de Ibáñez, 1946: 11).

El control sobre la ortodoxia indiana recaía en los obispos o arzobispos, pero a pesar de ello no se estableció claramente si el oficio sagrado tenía jurisdicción sobre las poblaciones indígenas, pues en la Recopilación de leyes de los reynos de Yndias (1943, libro I, título XIX: 159-179) se estipula que "los quales dichos Inquisidores han de conocer y conocen solamente de las causas de los Españoles, y no contra los indios [...]". ${ }^{24}$

En Yucatán donde, como ya se apuntó, la labor misional había comenzado más tarde, los frailes también vieron defraudada su esperanza en que la intensiva predicación había surtido el efecto deseado, y fue un rudo despertar cuando se descubrieron evidencias de prácticas idolátricas en Maní (1562). En consecuencia, Diego de Landa instituyó el famoso "auto de fe" cuyas prisiones y crueles métodos de tortura causaron profunda impresión en los mayas, quienes recordaban esa época con pavor. Como relata Lizana (1633, libro primero, primera parte, capítulo VIII: 13r): "Y fue tal el castigo y rigor y zelo santo, que el día de hoy está tan en la memoria entre los naturales que dizen, para alegar cosas de aquellos tiempos [...], el "tiempo de la cuelga"' (1995: 73). Los Libros de Chilam Balam (Barrera Vásquez y Rendón, 1948: 65-66) se refieren al comienzo y fin de esos tiempos aciagos: "Este es el año que corría cuando aconteció el colgamiento: 1562" y "Dentro de ese mismo katun (Katun 9 Ahau) llegó el primer obispo de nombre Toral. También cesó el colgamiento [...]".

Debemos apuntar cómo, por mucho que desaprobemos la severidad y los métodos represivos de Landa, conviene recordar que en nada se diferenciaban del rigor aplicado en el Viejo Mundo. ${ }^{25}$ Aunque eran hombres de hábito, frente a la enorme tarea de combatir la idolatría los religiosos caían presos de muchas de las mismas fallas de cualquier otro ser humano: en momentos se entregaban a la desesperación, la frustración y la ira porque los indios rechazaban el sumo bien que se les ofrecía y una y otra vez reincidían en sus antiguas prácticas. También

cos y conversos (Boxer, 1978: 84-85), y también para contrarrestar la amenaza de la fe musulmana, judaica y, más tarde, protestante. Como escribe López de Cogolludo (1971, libro VII, capítulo II: 12): "Nuestros reyes, como tan verdaderos hijos de la iglesia, y celosos de la observancia de su verdadera religión, determinaron que en estos reinos se estableciese el santo tribunal de la fe, para que con su piadosa solicitud no permitiese en ellos error alguno que la maculase".

${ }^{24}$ Hubo casos notorios, como el de Cazoncin y don Carlos de Tezcoco en que no se observó esta estipulación, razón por la cual se reprendió a Zumárraga y finalmente se le removió como inquisidor apostólico.

${ }^{25}$ Véase las ilustraciones y fotografías en la guía de la exposición de "Instrumentos de tortura desde la Edad Media a la época industrial" (presentada entre 1983 y 2000 en varias ciudades del mundo). 
es necesario juzgar sus acciones dentro del contexto del clima religioso de la época y la casi paranoica cacería de "idólatras".

En cuanto a Landa, éste se consideró en pleno derecho de instituir el auto de fe, pues la bula papal de Adriano V, Exponi nobis, había otorgado privilegios especiales a los clérigos regulares, con el derecho de ejercer casi todos los poderes episcopales, salvo el de ordenamiento, cuando no hubiera un obispo residente o éste viviera a una distancia de dos días de jornada. Por lo tanto, dejaba margen para que Landa lo interpretara a su modo y procediera como lo hizo.

En lo que sí se excedió Landa fue en la prisa con que llevó a cabo los procesos en el auto de fe, sin observar debidamente los procedimientos inquisitoriales y empleando la tortura en las fases preliminares. Sin embargo, como informa Lizana (1633, segundo libro, capítulo VI, párrafo 7, folio 110v), se le llegaría a absolver de todos los cargos "diziendo que, si no huuiera procedido como lo hauía hecho, huuiera pecado mortalmente", culpándolo tan sólo de "hauer llegado a todo rigor, por ser gente nueua los indios" (1995: 186); finalmente, el rey y su Consejo lo dio "por libre, y buen juez y ministro digno de toda honra" (id.).

En un proceso inquisitorial había una forma establecida para proceder contra el acusado de herejía. Después de haber presentado una denuncia formal basada en la observación de los movimientos del sospechoso, primero se hacía una investigación del caso y luego se encarcelaba al acusado. Inmediatamente después, el caso procedía con la presentación de testigos secretos, cuya credibilidad atacaba la defensa, y finalmente se mostraban testigos a favor del acusado (Lorca, 1953: 44-53). En cuanto al uso de la tortura, sólo al concluirse la causa y haberse verificado las pruebas al respecto, se sometía al acusado a ella, utilizando los cordeles, la garrucha y el agua en combinación con el burro o potro. Estos últimos procedimientos no fueron respetados por Landa (véase Scholes y Adams [1938], Mariel de Ibáñez [1946], Clendinnen [1982 y 1987]). ${ }^{26}$

También se puede cuestionar la severidad de la tortura empleada por Landa, ya utilizada con anterioridad: su uso fue introducido en 1252 por Inocencio IV mediante la bula Ad extirpanda, y se siguió recurriendo a ella en los siglos subsiguientes (Lorca, 1953: 61). Sin embargo, sólo se echaba mano de la tortura en la última etapa del proceso, en especial si no se podía probar ni la inocencia del acusado ni su culpabilidad. El propósito era lograr una confesión por medio del dolor, pero sin dejar heridas ni secuelas visibles de larga duración (ibid.: 66); mas en el auto de fe de Maní sí hubo lisiados y hasta muertos."

\footnotetext{
${ }^{26}$ Tras ser nombrado obispo, Landa desarrolló con rigor campañas de extirpación de la idolatría; su intensidad quedó probada en los autos de fe de Maní (1572, 1573 y 1576), Campeche (1573/1574), Concal (1576/1577), Cholul, Chicxulub y Motul, entre otros lugares (véase Chuchiak 2005: 623, mapa 1).

"Nota del editor: las investigaciones sobre los ritos idólatras en Maní no han podido confirmar si los tormentos aplicados a los prisioneros le provocó a alguno la muerte.
} 


\section{El Informe contra idolorum cultores}

Si bien los frailes hablaban de un "resurgimiento" de la idolatría, en realidad no había tal. El verdadero problema era que las antiguas prácticas religiosas sencillamente se llevaban a cabo a escondidas de noche o en cuevas, cavernas u otros lugares aislados de la península, tal como lo apuntó Motolinía (1988: 72) y como años más tarde lo recalcaría Sánchez de Aguilar.

Esto ocasionó que en 1603 Sánchez de Aguilar escribiera al rey sobre el asunto, escandalizado por el hecho de que, siendo provisor de sede vacante en el obispado de Yucatán, veía las cárceles "llenas de Indios idolatras" y "la idolatria tan crecida, y la justicia Eclesiastica tan desfavorecida en su castigo, y remedio" (1987: 21).

La respuesta de la corona fue promulgar una cédula real en 1605 para que el obispo informara sobre la causa de tanta idolatría en Yucatán y para hallar una solución adecuada (ibid.: 33-34). En carta del 12 de diciembre de 1605 el obispo Vázquez de Mercado escribe al rey: "Mándame Vuestra Majestad por otra su real cédula [...] informe si en este obispado hay indios que idolatran y qué es la causa que haya más de éstos que en otras partes, y si es necesario que el castigo sea más grave de lo que hasta aquí ha sido, por la relación que de esto ha hecho el doctor Pedro Sánchez de Aguilar [...]" (Scholes et al., 1938, 2a serie: 147). Como respuesta, el obispo contesta que sí, que la relación que ha hecho aquel es verdadera "porque cada día se van descubriendo más idólatras de nuevo, y el día de hoy tengo más de cuarenta y tantos para castigar” (id.).

Por su parte, en su carta a Felipe IV, Sánchez de Aguilar explica cómo había redactado su Informe contra idolorum cultores cuando era capellán y deán de la iglesia catedral de Yucatán, cuando se volvió como él mismo dice: "testigo ocular de la muy reñida y antigua competencia, que huvo, y avia (y pienso que oy dura) entre los dos braços, Real, y Eclesiastico cerca de la captura, prision y castigo de los Indios idolatras, y apostatas de aquel Obispado, donde estava la idolatria tan arraygada [...]" (1987: 17).

Sin embargo, cita un número de razones por las cuales no llegó a publicar su obra hasta muchos años más tarde (ibid.: 20): 1) primeramente, titubeaba en divulgar lo que consideraba "quizás amargara á algunos";27 2) aunque tuvo el propósito de imprimir el libro cuando pasó a España como procurador, se lo impidió su mala salud; 3) consideró su obra "indigna de muchos ojos por la cortedad de mi talento y la penuria de libros", otro motivo por el cual en tantos años no saliera a la luz [...]" (id.); 4) al ser nombrado canónigo de la Ciudad de la Plata, y estando en "la tierra mas cara que tiene el mundo", ya no le alcanzaron los medios para publicarla; 5) finalmente, con la pérdida del original de una Doctrina Cristiana en lengua maya (en la que reconoce haber modo".

27 Ya hemos visto páginas atrás que muchos religiosos lo consideraban un asunto "incó- 
trabajado más que en su informe), "desmayé, juzgando que mi trabajo era inútil" (id.).

Años más tarde, una vez superado aquel temor y animado por "tantos varones tan santos como doctos” (1987: 20) y por su misma conciencia, Sánchez de Aguilar finalmente decidió publicar el informe. El primero de enero de 1636, siendo canónigo de la santa iglesia metrópoli de La Plata, ${ }^{28}$ le escribió al rey desde esta última ciudad, informándole su decisión de imprimir la obra.

Asevera Sánchez de Aguilar (1987: 55): “Lejos de mí asegurar que todos los indios de esta Provincia sean idólatras, siendo principalmente el número de sus pobladores cien mil; pero sí que lo son cinco o diez mil, según las varias Provincias en que los hemos aprehendido despertigados, que caen y recaen algunos”. Cita además el caso de una provincia de dos mil varones donde gracias a la vigilancia del párroco se descubrió a cien idólatras; también da la noticia de Gonzalo Salazar sobre los recientes sacrificios de niños (id.).

También insiste en que la reincidencia se debe al poco castigo recibido por los idólatras; según él, precisamente por haber cesado los correctivos durante tantos años había crecido la idolatría (ibid.: 110). Trae a la memoria cómo reincidió Andrés Cocom, ahorcado en Campeche, y los recientes dogmatizadores, Alfonso Chable y Francisco Canal, quienes entonces estaban presos. En 1610 estos últimos se habían hecho pasar ante los suyos por papa y obispo, respectivamente, celebrando la misa a medianoche del modo católico, pero al mismo tiempo "adorando los ídolos que veneraban en el altar con incienso, ordenando sacerdotes para servir a los ídolos, ungiéndoles las manos con óleo y crisma santo, usando mitra y báculo, mandando colectas y ofrendas, profiriendo grandes herejías" (ibid.: 100).

Con enojo, el autor hace el siguiente reclamo: "nunca habíamos oído que los naturales hicieran esto en las Indias; ¿dónde se halla igual maquinación? ¿tal audacia? ¿tanta perfidia? [...] ¿dónde tantos idólatras? [...] ¿dónde tantos ídolos venerados en los altares y llevados procesionalmente?" (ibid.: 100-101). Naturalmente, el caso de Yucatán tenía mayor resonancia para él, pero más tarde, tras leer el libro de Arriaga, reconoció que el problema de la "idolatría” era aún más grave en el Perú (ibid.: 118). ${ }^{29}$

En el área maya los ásperos montes y numerosas cuevas, por estar alejados y ser de difícil acceso, brindaban amplia oportunidad a los indios para celebrar sus ritos sin ser descubiertos; Sánchez de Aguilar (1987: 35-36) en su octavo fundamento dice al respecto:

En esta Provincia de Yucatán por todos lados, desde el promontorio que los navegantes llaman Cabo de Catoche, hasta lo último, es una y sola montaña plana,

\footnotetext{
${ }^{28}$ Las Charcas, Perú.

${ }^{29}$ Hemos visto cómo De la Serna, quien escribe casi veinte años más tarde desde Oaxaca, concuerda en que la idolatría seguía latente.
} 
pero de tal manera densa y oscura por la multitud de árboles y hierbas, que cualquiera fácilmente puede esconderse y a diez pasos del camino no puede ser visto de los transeuntes; en dichas montañas hay innumerables cuevas, y cavernas entre piedras, donde adoran y esconden sus ídolos los indios [...].

Años atrás (hacia 1580) las Relaciones histórico-geográficas de la gobernación de Yucatán (De la Garza, 1983) ${ }^{30}$ afirmaron que los indios tenían "ídolos" en los montes y las milpas, lugares inaccesibles donde escapaban a la vigilancia de los frailes y llevaban a cabo sus ceremonias.

Estos indios han tenido desde su gentilidad sus ídolos que han adorado, y aún agora se tiene por cierto que hacen lo mesmo y que adoran unos ídolos de barro, los cuales dicen tienen en sus casas escondidos y en los montes y milpas adonde los van adorar y sacrificar [...] (De la Garza et al., 1983, tomo II: 277). ${ }^{31}$

De tres años a esta parte, los frailes han sacado de los dichos indios ídolos que adoraban, que tenían escondidos en sus casas y cuevas [...] (ibid.: 336). ${ }^{32}$

Además, los frailes ya habían comprobado lo difícil que era encontrar pruebas del delito; De la Serna (1987: 471) recalca la mucha maña necesaria para ello, porque: "en no cogiéndolos con la obra en las manos, todo lo niegan, y esconden todos los instrumentos con que obran [...]". Apunta también que los ministros

Han de ser como serpientes, para descubrir sus fraudes y engaños, y entenderlos, y conocerlos con tanta prudencia, y astucia cristiana, que affectando ser muy de su parte en aquellos delictos [...] sea solo á fin de atraerlos, para que sin negar cosa confiessen su culpa [...]. [Y] affectar los Ministros mostrar curiosidad en quererlo ver todo, y saber las palabras, y modo de sus idolatrias, para asegurarlos, y hazerles que confiesen (ibid.: 472).

En Yucatán la evidencia de idolatría descubierta en Maní en 1562, y que desencadenó el famoso proceso inquisitorial, no fue resultado de pesquisas hechas por los frailes, sino de informes proporcionados por uno de los mismos indios. ${ }^{33}$ Lizana $\left(1633\right.$, libro $2^{\circ}$, par. $5^{\circ}$, cap. VI 105r) nos deja una descripción de lo descubierto por el portero cuando, siguiendo a su perrillo, entró en la cueva:

Y el indio, admirado, se entró en la cueva y fue poco a poco, por el olor de los sahumerios de copal y incencio de la tierra, y llegó a ver, en lo más hondo de la

\footnotetext{
${ }^{30}$ En los siguientes pasajes utilizo para esta fuente la abreviación RHGGY.

${ }^{31}$ Cita de la "Relación de Sacalaca y Tahmuy" (RHGGY).

32 Cita de la "Relación de Yalcon" (RHGGY).

${ }^{33}$ López de Cogolludo (1971, libro VI, cap. I: 410) y Lizana (1995:180) aseveran que fue Pedro Che, portero del monasterio quien, estando cazando con sus perros, descubrió evidencia de ido-
} 
cueva, más altares y mesas muy compuestas y, allí, muchos ídolos y la sangre del venado fresca con que los havian roziado poco havia [...] (1995: 180).

Enterado, Diego de Landa inició las investigaciones que culminaron en el auto de fe, si bien refiere el hecho en forma lacónica y muy circunspecta, no dejando entrever su reacción que, dado su carácter y los siguientes acontecimientos, debió haber sido violenta:

Que estando esta gente instruída en la religión y los mozos aprovechados, como dijimos, fueron pervertidos por los sacerdotes que en su idolatría tenían y por los señores, y tornaron a idolatrar y hacer sacrificios no sólo de sahumerios sino de sangre humana, sobre lo cual los frailes hicieron inquisición y pidieron la ayuda del alcalde mayor prendiendo a muchos y haciéndoles procesos; y se celebró un auto [de fe] en que se pusieron muchos cadalsos encorozados. [Muchos indios fueron] azotados y trasquilados y algunos ensambenitados por algún tiempo; y otros, de tristeza, engañados por el demonio, se ahorcaron, y en común mostraron todos mucho arrepentimiento y voluntad de ser buenos cristianos. (Landa, 1986: 32).

A juzgar por lo que sabemos del entonces provincial y futuro obispo, Lizana (1633, libro $2^{\circ}$, par. $5^{\circ}$, cap. VI: $105 \mathrm{v}-106 \mathrm{r}$ ) refleja un poco mejor el estado de ánimo de Landa que las propias palabras de éste:

partió como un rayo para Maní para poner remedio en tal idolatría y castigar tal desverguienza como la que se descubrió [...]. Y llegado que fue [...] a pocos lances descubrió la llaga solapada y, con la autoridad apostólica que tenía por los Breves del Papa, haziendo oficio de Inquisidor comenzó a proceder contra los idólatras apóstatas de la fe. Y, hechas las informaciones, pidió el auxilio Real, que se le dio luego, y comenzó a prender indios y [a] castigarlos en acto público [...]. Descubrió, [assí mismo], otras idolatrías hazia los Cupules, Cochuahex de Zututz, Canules y otras [provincias], y, a los que dellos havían muerto idólatras antes desto, los mandó desenterrar y arrojar a las fieras por haver sido convencidos de idólatras, apóstatas de la santa fe. Hizo, assí mismo, junta de los libros y caracteres antiguos, y los mandó quemar (1995: 181). ${ }^{34}$

Como había dicho Lizana páginas atrás $\left(1633\right.$, libro $1^{\circ}, 1^{\mathrm{a}}$ parte, cap. VIII, 13v), "[era] tan perseguidor de los idólatras hechiceros [...], no bastando amo-

\footnotetext{
latría en una cueva. Sin embargo, en el testimonio dado durante el auto de fe (Scholes y Adams, 1938) se dijo que los informantes fueron dos niños del convento-escuela.

${ }^{34}$ López de Cogolludo (1971, libro VI, cap. 1: 410-411). Habiendo pedido el auxilio del alcalde mayor, fue a Maní con la mayoría de la nobleza española, "asi para la autoridad del acto, como para la seguridad de lo que pudiese acontecer" (id.). Habiendo concurrido gran número de indios, mandó juntar todos los códices y para quitar a los indios "toda ocasión y memoria de sus antiguos ritos" (id.) los mandó quemar públicamente. Comenta López de Cogolludo: "aunque los émulos de el bendito padre le dieron título de cruel, pero bien diferentemente sintió de la accion el doctor D. Pedro Sanchez de Aguilar" (ibid.: 411).
} 
nestaciones, que los colgava de perchas para que manifestassen los idolos y declarassen las hechicerias [...]" (1995: 73).

Los procesos (Scholes y Adams, 1938) dejan entrever el rigor con el cual se procedía, incluyendo el uso desmedido de la tortura. Se encarcelaba a los indios sumariamente y aquella se les aplicaba libremente: el burro, el tormento de agua, el de cera caliente, etcétera. En carta enviada por los indios gobernadores de varias provincias a Felipe II ellos se quejan de estos atropellos, cometidos por los franciscanos (Cartas de Indias, 1877: 407). ${ }^{35}$

Los indios, alterados por las medidas draconianas de Landa y sus frailes, estaban a punto de alzarse, poniendo en peligro el dominio de la corona sobre Yucatán. Los encomenderos y oficiales del rey temían una sublevación, y ya se discutía la posibilidad de enviar una delegación a la Ciudad de México para presentar quejas ante el virrey y el protector de indios. Diego Rodríguez Bibanco llegó al extremo de pedir que se sacaran a todos los franciscanos de Yucatán (Cartas de Indias, 1877: 392-396).

Con el nombramiento de Toral se calmarían los ánimos, tanto de los indios como de los españoles, en particular porque éste emplearía métodos diametralmente opuestos al rigor de Diego de Landa y su grupo. Aunque también era de la orden franciscana, Toral criticó abiertamente el proceder de su predecesor, prohibió la tortura y, juzgando con clemencia, impuso penas leves a los reincidentes. Como su provincial (Landa) fue requerido en España para responder a los cargos formulados en su contra con motivo del auto de fe, los frailes creyeron prudente moderar su modo de proceder contra los indígenas.

Por el momento había vencido el grupo de frailes moderados (que optaban por métodos más benévolos) sobre quienes, como Landa y más tarde el propio Sánchez de Aguilar, favorecían el uso de la mano dura, el único método eficaz, a su modo de ver, para contrarrestar la idolatría. Sin embargo, los últimos lograron dejar su imprimatur en el siglo xvI; obsesionados con el problema de la idolatría y su aparente rebrote, los frailes mantuvieron su inflexibilidad e intolerancia hacia los indígenas.

Al morir Toral, la época de relativa moderación llegó a su fin. Bajo la dirección interina de Cristóbal de Miranda, deán de la catedral, los franciscanos renovaron sus campañas para la extirpación de la idolatría (Chuchiak, 2005: 619). Esta actividad recibió renovado ímpetu con la llegada de Landa a quien, en 1573, se le encomendó el obispado de Yucatán. Como lo apunta Chuchiak (ibid.: 620), durante su actividad obispal procesaría más mayas por el crimen de idolatría que durante su infame auto de fe de 1562, con métodos igualmente crueles.

\footnotetext{
${ }^{35} \mathrm{Si}$ nos detenemos en este proceso es porque Sánchez de Aguilar lo toma como ejemplo, saliendo en defensa de Landa contra sus detractores y dando su aprobación a los métodos represivos utilizados. Recordemos cómo, a pesar de ser el más célebre auto de fe, este proceso estaba lejos de ser el único (véase Chuchiak, 2005).
} 
Pero además de la idolatría había otras preocupaciones. El siglo xvII venía arrastrando numerosos problemas ya manifiestos durante la centuria anterior: desavenencias entre frailes y encomenderos, disputas entre aquellos y el poder temporal, y rivalidad entre los frailes y el clero secular tanto por beneficios como por prebendas. Poco después de la Conquista, los encomenderos y oficiales del rey comenzaron a rivalizar con los religiosos por dominar a los indios y veían con malos ojos su creciente influencia entre los mismos. También resentían sus constantes quejas y amonestaciones contra el maltrato a los indígenas y sus recomendaciones a favor de una actitud más humana y justa, considerando el hecho una intromisión en su competencia y una amenaza para su autoridad e intereses creados. Finalmente, también se gestaban conflictos entre encomenderos, oficiales del rey y autoridades de la Iglesia, por una parte, y la población indígena por otra, cuya forma de vida y creencias se intentaban destruir y reemplazar por creencias hispanocristianas.

Al principio de la labor misional, la conversión había corrido por cuenta de órdenes mendicantes como los franciscanos, la única que operaba en Yucatán. Mas para fines del siglo se fueron incorporando otras órdenes religiosas a la labor misional, generando renovadas rivalidades entre las distintas cofradías. Los conflictos continuaron, sumándose las ya agudizadas diferencias y querellas entre el brazo civil y el eclesiástico sobre el derecho a aprehender, juzgar y castigar a los indios idólatras.

Por otra parte, iba aumentando el número de la clerecía secular; con esto las preocupaciones religiosas tomarían un cariz más mundano, más práctico. Además, con el tiempo se acrecentaron las desavenencias entre las órdenes mendicantes y el clero secular, tanto por la competencia sobre los indios como por asuntos relativos a los beneficios y doctrinas que se debían administrar.

Al morir Carlos V, quien siempre había favorecido a los mendicantes, y al asumir el trono su hijo Felipe II, los frailes perdieron favores en la corte, como lo demuestran sus amargas quejas (Cartas de religiosos de Nueva España, 1941: 169-178). Felipe II no los privilegiaba como lo había hecho su padre; en cambio, alentaba las pretensiones de los seculares. Según Phelan (1970: 87), desconfiaba de los frailes, por lo cual se volvió un aspecto decisivo de su política limitar su influencia.

Además, como apunta Boxer (1978: 66), uno de los principales objetivos del Concilio de Trento (1543-1564) fue fortalecer la autoridad del prelado diocesano en cada fase de la vida religiosa y de la disciplina eclesiástica dentro de su territorio. Esto causó un conflicto entre los extensos privilegios de las órdenes religiosas y los derechos jurisdiccionales de los obispos. El problema jamás se resolvería, aún a lo largo de todo el periodo colonial, pues ni el papado ni las dos coronas ibéricas eran consistentes en sus actitudes respectivas, alternativamente apoyando una parte o la otra.

Ya no era cuestión, como al inicio de la conquista, de proselitismo, de ganar almas o de establecer una segunda Jerusalén en el Nuevo Mundo, como lo soñó Mendieta (1980). La labor misionera ya se había llevado a cabo; restaba afianzar 
el poder del cristianismo y asegurar que los indios no recayeran en sus antiguas creencias y ritos. El enfoque de la época que tratamos (entre 1560 y 1660) era, por lo tanto, de consolidación; había que asegurar lo ganado pues, en lo religioso, el reto era luchar encarnizadamente contra la idolatría.

Sánchez de Aguilar, cuya preocupación al respecto rayaba en el fanatismo (como Landa), atribuye su rebrote precisamente a las desavenencias y disputas de gobernadores y justicias con los prelados y a los impedimentos resultantes. Insiste: si se le hubiese prestado el auxilio debido al obispo doce o quince años atrás, apresando y enviándole a los idólatras, o si se hubiesen pregonado los castigos que recibirían los indios al volver a sus antiguas prácticas "este pecado no se habría aumentado" (1987: 45). Pero, por el contrario, "se ocupaban dichos jueces en cuestionar con los obispos sobre la jurisdicción y conocimiento en las causas de idolatría, rehusando que los demás les prestasen o diesen el auxilio que ellos mismos les prohibían" (id.). Más adelante cita al respecto a Don Antonio Daza (1987: 121), quien lamenta:

Desdichados los Governadores, y Justicias de aquella tierra, que por una leve competencia de juridición [sic] con los Prelados, y Pastores, son causa de que no se aparten las simples ovejuelas de las dentelladas del lobo infernal, ligando, y entumeciendo como serpientes encantadas las manos de los Obispos, para que con el báculo no recojan el ganado, y con el silvo no espanten al lobo.

Estas rencillas afectaban directamente la labor religiosa y Sánchez de Aguilar recalca "cuán antigua e inextinguible es la controversia entre el juez real y el eclesiástico tocante a prestar auxilio y aprehender a aquellos que adoran ídolos [...]" (ibid.: 69). Por su parte, De la Serna (1987: 453) subraya la necesidad de cooperación entre los alcaldes mayores y los ministros de la doctrina: "que no se remediarán tantos daños como ay, menos que con este remedio [...] [y] es forçoso el auxilio, y favor, y defensa de los Príncipes, y Ministros suyos para la authoridad y defensa de la Religión".

El recrudecimiento de las respectivas posturas se debía en gran parte a que, como ya se ha apuntado, la corona había optado por limitar la esfera de influencia de los religiosos; en particular, les quitaba el poder de aprehender y castigar a los indios, prohibiéndose los métodos severos de castigo que se habían usado. Estas limitaciones se hallan reflejadas en el Cedulario de Puga (1879), el Cedulario indiano (1945) y la Recopilación de leyes de los reynos de las Indias (1943) ${ }^{36}$ La nueva insistencia de la corona en acabar con el maltrato de sus nuevos súbditos en el Nuevo Mundo iba dirigida tanto contra los encomenderos como contra los religiosos.

Sánchez de Aguilar encontró una relación directa entre estas nuevas medidas que promulgaban una política moderada hacia los indios y el renovado rebrote de idolatría. Su propia convicción era que sólo "con mano fuerte" se

${ }^{36}$ Véase al respecto Sánchez de Aguilar 1987: 30-31. 
podía dominar a los indios y mantenerlos dentro del sendero trazado por la moralidad cristiana, y citaba la opinión de Antonio de Guevara: "la demasiada tolerancia y paciencia en castigar, aumentan y favorecen los delitos" (1987: 46). Y sigue diciendo Sánchez de Aguilar: "Porque si los jueces eclesiásticos tan solo procedieran con censuras contra estos idólatras quedarían impunes [...] Por lo tanto deben ser aprehendidos, encarcelados con mucha vigilancia, y engrillarlos si se juzgare conveniente" (ibid.: 47). Lo mismo opinaban sus contemporáneos Jacinto de la Serna, Gonzalo Balsalobre y otros, advirtiendo que era necesario y útil castigar a los idólatras con mucho rigor; de lo contrario, según ellos, no olvidarían a los dioses y ritos de su pasado.

Sánchez de Aguilar aboga por aplicar penas corporales "que desde remotos tiempos con esta clase de gentes se sabe haberse practicado" (1987: 51), juzgándolos "no como paganos, sino como apóstatas de la Fe que sus antepasados ya recibieron una vez" (id.). Insiste: "ahora que ha aumentado su malicia, audacia e insolencia, no es conforme a razón, que semejantes delitos se corrijan con lenidad, sino con severo castigo, y digno de tal delito" (Sánchez de Aguilar, 1987: 105). Después asevera que: "Luego si se puede combatir a los idólatras, mucho más se les puede desterrar, ahorcar, quemar, según dispone el Derecho" (ibid.: 56).

A través de estas citas podemos constatar cómo una actitud inicialmente más benévola fue cediendo a otra más dura e inflexible, de la cual es ejemplo por excelencia el obispo de Landa. Al comenzar la labor misional se consideraba a los indios como nuevos en la fe, a quienes se había de atraer a la cristiandad por medio de la bondad y del ejemplo. Sin embargo, aún en esa época, algunos frailes del grupo que podríamos llamar moderados, por ejemplo Mendieta, veían en el castigo y el temor los únicos medios para hacer de los indígenas buenos cristianos. Obviamente, las palabras caritativas a menudo no estaban de acuerdo con la inclinación de castigar la más mínima falta.

A los indios se les consideraba "párvulos y niños" (Códice Mendieta: tomo I: 103); "puramente niños, naturalmente subjetos y timidos" (Cartas de religiosos de Nueva España, 1941: 10), con el talento y capacidad de "mozuelos de hasta diez ó doce años" (Códice Mendieta, 1971, tomo II: 8) y, por lo tanto, con perpetua necesidad de ayos. Se llegó a aseverar que "quitarles el templado castigo es destruirlos" (Scholes et al., 1938, $2^{\text {a }}$ serie: 97). ${ }^{37}$ El mismo Mendieta, mientras exaltaba su buena disposición para ser buenos cristianos, capaces de llegar a ser "angélicos" o "sin pecado" con la ayuda de los religiosos, aseveró que para inculcarles la doctrina y vida cristianas era necesario usar el clavo y el martillo. Es más, llegó a insistir en que les era: "tanto menester el azote como el pan de la boca, y tan natural, que entre sí no se hallan ni pueden vivir sin ello, y ellos mesmos lo confiesan, que en faltándoles el azote como niños son perdidos" (Códice Mendieta, 1971, tomo II: 9).

${ }^{37}$ En el Memorial del Provincial y Definidores al Real Consejo de las Indias (ibid.: 95-101). 
Luego de haberles predicado, enseñado y haber sido bautizados, ya no se juzgaba a los indios con la misma indulgencia. Al recaer en sus antiguas prácticas, pasaron de ser "plantas nuevas en la fe" a rebeldes y herejes a quienes sí se les podía juzgar con mucho más rigor.

\section{Definición de apóstatas, herejes e idólatras}

Precisamente en este punto se apoya Sánchez de Aguilar (1987: 57):

los indios de esta Provincia, que por 80 años conocieron nuestra Fé mediante la gran doctrina de varones religiosísimos de la orden de San Francisco, y de algunos clérigos que hasta hoy cuidan de este rebaño [...] han recaído en su idolatría no por falta de predicadores, sino, debe decirse por su insolencia, pertinacia y pereza.

Y, por lo mismo, recomienda mejor "aplicar la medicina corporal en tiempo oportuno, que después de la crudeza de la enfermedad resiste a los principios; tarde viene el remedio cuando la llaga es muy vieja" (ibid.: 55). Coincide con él De la Serna (1987: 462), pues dice: "no puede haver mayor servicio á Nuestro Señor, que reducir el celo de su honra á el castigo de los transgresores de su Religión; pues con el castigo de unos se enmiendan otros".

Para Sánchez de Aguilar (1987: 23) sin duda el castigo de la idolatría caía dentro del ámbito exclusivo de la Santa Madre Iglesia, pues "la causa de Dios [...] es propagar la Fe y extinguir de raíz entre los habitantes del reino yucateco la herejía, cual es la detestable idolatría". Expresa su convicción de que la vigilancia contra los herejes, y por extensión su aprehensión y castigo, formaba parte íntegra de esta labor y de que en la disputa al respecto entre jueces eclesiásticos y oficiales del rey, la Iglesia debía imponerse. Por ello, en su Informe contra idolorum cultores defiende el derecho exclusivo de los obispos a juzgar causas de idolatría pues esta materia, al tratarse de la conciencia y del alma de los feligreses, caía dentro de su ámbito: "quien podrá dudar que dicho conocimiento tan sólo pertenece a los obispos cuando proceden del $2^{\circ}$ modo [obrando como inquisidor] [...] pues el pecado de idolatría es herejía o apostasía en el bautizado [...]" (ibid.: 49). Recalca además cómo: "los sacerdotes deben ser consultados en nuestro caso sobre castigar y aprehender a los idólatras, quienes por experiencia, trato, constante unión, administración y conversación conocen a los indios por dentro y por fuera, que saben sus costumbres, las dolencias que padecen [...]" (ibid.: 63).

Pero precisamente allí estaba la clave de la disputa entre el brazo civil y la Iglesia, pues de acuerdo con las nuevas disposiciones de la corona para limitar el poder de los religiosos, ya no quedaba muy clara la división de competencia. La Cédula de 1560 prohibía a los religiosos tener cepos o cárceles, y se ordenaba al gobernador o a sus lugartenientes o justicias asegurarse de que "por ninguna 
vía (tuvieran) dichas cárceles, ni se prendan, trasquilen, azoten a ningún indio [...] y si alguno estuviese preso lo suelten" (Cedulario de Puga, 1879, tomo II: 348-349, hoja 201 v). Todavía más al caso eran las recientes cédulas donde se prohibía a los prelados y jueces eclesiásticos prender o hacer ejecuciones en personas legas o en sus bienes, dejando claramente establecido que para ello debían valerse del brazo civil: "Salvo, que quando los dichos juezes Eclesiásticos quisieren hazer las tales prisiones, y execuciones, pidan, y demanden auxilio de nuestro braço Real a las dichas nuestras justicias seglares, los quales lo impartan quanto con derecho deban"38 (Sánchez de Aguilar, 1987: 25).

Por medio de esta cédula se extendía a los jueces reales la jurisdicción sobre los indios. No obstante, si en principio los religiosos y prelados no eran renuentes a cooperar con el brazo civil, no admitían hacerlo por coacción sino por voluntad propia, pues consideraban que todo asunto relativo a la fe caía exclusivamente dentro de la jurisdicción de la Iglesia.

Un ejemplo de este tipo de cooperación ocurrió durante el auto de fe de Maní cuando Diego de Landa pidió al alcalde mayor Diego Quijada hacer acto de presencia. Esto obedecía a consideraciones puramente pragmáticas y no a cuestiones de índole jurisdiccional, pues Landa buscaba dar mayor legitimidad a su proceder, además de infundir pavor entre los indios. Aunque los religiosos habían determinado de antemano los métodos a seguir durante el proceso, el alcalde y sus oficiales, en efecto, eran parte del plan para dejar claro y sin dejar lugar a dudas que los indios no tenían derecho a recurso ni a apelación, pues en este proceso se les juzgaba para todos los efectos tanto por lo religioso como por lo civil.

Mas para cuando escribía Sánchez de Aguilar, la situación había cambiado y éste deja bien claro cómo era precisamente esta falta de cooperación del brazo civil con el eclesiástico la principal dificultad para lograr la extirpación de la "idolatría", además de socavar la autoridad de los religiosos sobre los indios. Culpa a los jueces reales de tibieza y se queja de su falta de apoyo. Expresa su frustración por las limitaciones impuestas sobre el poder de la justicia eclesiástica para castigar a los indios. También De la Serna (1987: 453) recalca la importancia de la cooperación entre los alcaldes mayores y los ministros de doctrina: "Para remedio, pues, de los daños que se reconocen en estas idolatrias, y supersticiones de los indios [...] no solo es menester el auxilio, que su Majestad da para la execucion en estas materias, sino el que sus Excmos. Sres. Virreyes en su nombre conceden con tanta piedad, y zelo Christiano [...]". Vuelve a insistir en que sólo con la ayuda de los alcaldes mayores, actuando juntamente con los ministros en "union y concordia", se podrían remediar tantos daños (id.): "Es forçoso el auxilio, y favor, y defensa de los Principes, y Ministros suyos para la autoridad y defensa de la Religión" (id.).

\footnotetext{
38 "Cédula que ganó Don Gregorio de Funes, sobre el absolver a reincidencia, año 1599 insertas las leyes del reyno" (en Sánchez de Aguilar 1987: 25-26).
} 
Sin embargo, éste no era el único conflicto, pues se trataba de mucho más que una simple disputa entre el brazo civil y el religioso: había además una variedad de conflictos multidimensionales y fluctuantes. Como se apuntó más arriba, se venían arrastrando desde el siglo anterior viejos problemas: desavenencias y rencillas entre encomenderos, colonos, oficiales del rey y religiosos, una división dentro del seno de la misma Iglesia, y rivalidades entre los mendicantes, el clero y, posteriormente, entre las diferentes órdenes.

Los conflictos no siempre eran claros, pues las alianzas entre un grupo y otro cambiaban de acuerdo con la situación del momento y, desde luego, con los intereses de cada uno. A pesar de la rivalidad entre mendicantes y seculares, cuando estaba amenazada la jurisdicción de la Iglesia se unían para presentar un frente unido contra el brazo civil. Como defensores de los indios, abogaban por un mejor trato para ellos, pero en caso de una amenaza de rebelión indígena se unían a los oficiales del gobierno. Por su parte, los indígenas estaban más cerca de los frailes pues estos generalmente eran más benévolos y protectores que los encomenderos; pero si se sentían vejados por los frailes, no dudaban en acudir a las autoridades civiles. Explotados desde cualquier flanco, los indios aprovechaban cualquier oportunidad para contrapuntear situaciones, en un vano esfuerzo por sacar alguna ventaja.

Aunque en parte, el Informe contra idolorum cultores refleja estos conflictos, pues principalmente trata la disputa entre la Iglesia y el Estado sobre la salud espiritual de los indios. Con sus propias palabras, Sánchez de Aguilar nos dice que escribió su informe: "movido de ver como se impedía, o dilatava el castigo destos idolatras por la competencia de las dos cabeças cerca de la prision y conocimiento desta causa, que tantos años ha durado (y pienso que oy dura)" (1987: 118). Como dijera en su prólogo, el propósito de su Informe era probar "quan desenfrenadamente se van al infierno estos idólatras, no siendo rudos, ni bárbaros, ni neófitos, sino tan sabidos y resabidos y atrevidos, como larga y forçosamente lo pruebo, con sus maldades, y hechos insolentes, fundados en el poco castigo que han tenido [...]" (ibid.: 21).

$\mathrm{Al}$ examinar la competencia del brazo eclesiástico para juzgar casos de idolatría, Sánchez de Aguilar procede a modo de disputatio. Comienza abogando por la parte contraria, basándose en cinco argumentos (ibid.: 24-28); después los rebate uno por uno y recalca su propia posición: 1) que como personas seculares los indios no estaban sujetos al obispo y, por lo tanto, no podían ser aprehendidos ni encarcelados; 2) que se le prohibía a los obispos apresar por propia autoridad a personas legas, exigiéndoles valerse del auxilio del brazo secular (ibid.: 25); 3) que los indios eran neófitos "como plantas sin raíz, como párvulos en el conocimiento profundo de lo que mira a nuestra religión" (ibid.: 7); 4) así, como recién convertidos e "ignorantes, rústicos, bárbaros" (ibid.: 28) no se les debía castigar con el rigor que merecían sus delitos; 5) finalmente alega que, si en efecto se procedía como prevenía el derecho, entregándolos al brazo secular para imponerles la última pena, serían quemados. Al ver el castigo, los indios no querrían abrazar la fe. 
Tras señalar estos puntos, Sánchez de Aguilar procede a rebatir los argumentos señalados y propone diez razonamientos (ibid.: 28-41) con los cuales defiende su posición: el conocimiento de causa en casos de "idolatría", en efecto, le incumbía exclusivamente al brazo eclesiástico.

Como punto básico de su defensa, y rebatiendo el tercero y quinto de los argumentos contrarios arriba apuntados, recalca que, con excepción de los itzaes, los indios se habían reducido a la fe y la habían abrazado espontáneamente; por lo tanto, ya no se les podía considerar neófitos. Luego señala cómo todos, desde niños, habían aprendido y sabían completamente la doctrina cristiana, sin existir domingo en que antes de la misa mayor no la dijesen en voz alta ante todos los congregados. Por lo tanto, no se les podía calificar de neófitos o excusarlos como ignorantes de sus deberes cristianos, lo cual invalidaba el quinto argumento (punto sobre el cual vuelve Sánchez de Aguilar en su séptimo alegato).

En cuanto al efecto del castigo, Sánchez de Aguilar defiende su aplicación como efectiva. Toma como ejemplo la acción de Landa y sus compañeros de orden, quienes "extinguieron con todo vigor y esfuerzo este pecado, de modo que por algunos años se apoderó el temor de los indios, y no sólo abandonaron la idolatría, sino además las bebidas [balché $]^{39}$ que tomaban en sus libaciones" (ibid.: 29).

El autor defiende al miedo como el medio eficaz para hacer a los indios abandonar la idolatría, y en el quinto punto de su disputatio sale en defensa de Landa y de su actuación en el auto de fe, subrayando cómo había obrado de acuerdo con la Bula Omnímoda, y cómo las cédulas reales dictadas contra las medidas severas de Landa habían perjudicado a la Iglesia: "Digo y afirmo, que [la causa de estar la idolatría arraigada más en este obispado, que en otros es] el aver ido a la mano al segundo Obispo don Diego de Landa en castigar este pecado" (Sánchez de Aguilar, 1987:109).

Como prueba de que el obispo sí podía proceder contra los idólatras sin el auxilio del brazo secular, Sánchez de Aguilar arguye el caso de fray Gregorio Montalvo quien, siendo obispo, mandó azotar indios idólatras sin ayuda del brazo secular. Y aunque el rey recomendaba al gobierno de la provincia la extirpación de la idolatría, no le daba autorización para tratar el asunto porque era "enteramente eclesiástico" (ibid.: 33), a pesar de las quejas de algunos gobernadores al respecto. En aquella oportunidad el mismo Sánchez de Aguilar rompió ídolos y con el consentimiento del obispo los arrojó al mar.

Para fundamentar la supremacía de la Iglesia en dichos asuntos, Sánchez de Aguilar llama en su favor los pareceres de peritos como Azevedo, Gutierrez, Bobadilla, etc. "A estos doctores debe consultarse, pues son grandes intérpretes de las reales leyes civiles, quienes no vacilaron en dejar á nuestra santa Madre Iglesia lo que concede el Derecho, cual es el conocimiento de la idolatría, de aprehender a los idólatras sin auxilio" (1987: 44).

${ }^{39}$ Lonchocarpus longistylus Pittier (Mendieta y del Amo, 1981: 201). 
También recalca en su quinto fundamento que "por la suma paciencia de los obispos y por el leve castigo que se les imponía” (ibid.: 33), los indios se desenfrenaban y volvían a recaer en sus antiguas prácticas. Como resultado, el 9 de diciembre de 1608 la corona expidió una cédula otorgando al obispo el poder de proceder contra los idólatras, empleando los medios "que os pareciere mas convenientes" (ibid.: 34). A los pocos meses (el 24 de marzo de 1609) se expidió otra, reprehendiendo al gobernador Carlos de Luna y Arellano por sus malas relaciones con los religiosos franciscanos, y se despachó mandamientos para los gobernadores y alcaldes de indios porque no daban apoyo a los religiosos y clérigos para castigar a los indios por sus delitos, "de que resultara el perderles el respeto, y vivir sin ningun miedo" (ibid.: 34).

En su sexto fundamento, Sánchez de Aguilar recalca la existencia de muchos franciscanos y clérigos diocesanos capaces de hablar y predicar en el idioma de los indios, réplica sin duda a los detractores que de tiempo en tiempo acusaban a los frailes de falta de celo y de no saber el idioma de los indígenas.

Un punto importantísimo en su alegato es que lo montañoso de la península y la existencia de tantas cuevas y cavernas brindaban amplia oportunidad para idolatrar, pues allí los indios escondían y adoraban a sus ídolos. Comenta cómo muchas veces los religiosos no se percataban de estas "idolatrías", aunque cuidaban "como Argos con cien ojos, el rebaño que se les confía" (ibid.: 36). Pero, aún cuando se llegasen a descubrir estas prácticas, Sánchez de Aguilar pregunta: "icuándo, dónde, y en qué instante puede solicitarse el auxilio del brazo secular?", y formula el caso de una provincia ubicada hasta a cincuenta leguas de la ciudad donde residía el gobernador (id.).

Aunque en forma diplomática Sánchez de Aguilar califica las disposiciones del Real Consejo como sabiamente promulgadas y dispuestas, insiste en que eran más adecuadas para la labor incipiente de la Iglesia en las Indias que para el siglo xvil. Según él, los tiempos habían cambiado y si el rey o su Consejo examinaran la cuestión en esos momentos, se darían cuenta de la necesidad de cambiar, limitar, explicar o aún de anular las disposiciones anteriormente dictadas (ibid.: 40).

El último fundamento es determinante, y Sánchez de Aguilar vuelve a examinar la competencia de la Iglesia en estos asuntos frente a la del brazo gubernamental. De acuerdo con su exposición, el obispo en efecto puede proceder algunas veces en causas civiles o criminales: civilmente contra personas legas, y criminalmente al inquirir causas de fe como la herejía. En el primer caso, obra tan sólo como juez eclesiástico en las diarias causas forenses; en el segundo, no como eclesiástico sino como inquisidor contra la herejía cuando le incumbe "usar de igual derecho, autoridad y potestad que los inquisidores generales" (1987: 41-42). Cita como ejemplo la provisión que nombró al licenciado don Francisco Tello de Sandoval como inquisidor (1543), con facultad para proceder contra los herejes y apóstatas así como para encarcelarlos, penitenciarlos, punirlos y castigarlos. 
En resumen, Sánchez de Aguilar presenta dos conclusiones. En la primera expone que en causas civiles o criminales, ejecutadas civilmente, el obispo o vicario general (o foráneo) no puede aprehender personas laicas ni secuestrar sus bienes sin pedir el auxilio del brazo secular. La clave está en la frase intentadas civilmente. Ya anteriormente había hecho la distinción entre los dos modos de proceder: 1) "Tan sólo como juez eclesiástico en las causas diarias"; pero 2) "como inquisidor contra la apostasía" (ibid.: 40). Por lo tanto, según su segunda conclusión con esta última capacidad el juez eclesiástico sí puede proceder contra "los indios idólatras como a herejes, apóstatas (o) y despreciadores de nuestra Religión Cristiana" (ibid.: 43) sin solicitar el auxilio del brazo secular, "particularmente si proceden para el castigo del delito, para satisfacer por él a Dios Óptimo y Máximo, para reducirlos a verdadera penitencia, para que no vuelvan a los montes, donde no es fácil que los encuentren [...]" (id.).

Tras invocar los pareceres de doctores expertos en la materia (Covar, Azevedo, Cervera, Gutiérrez, Bobadilla, etc.), Sánchez de Aguilar asegura la coincidencia de ellos con su propia opinión (1987: 105). Es decir, la Iglesia sí tiene el derecho y la supremacía en asuntos de idolatría y el obispo puede actuar como inquisidor en casos de herejía y aprehender, encarcelar y azotar a los indios apóstatas para satisfacer a Dios. También invoca la cédula de 1608 que parece darle el poder al obispo para castigar y reprimir a los idólatras como le pareciere (ibid.: 48), "que todo lo merecen los idólatras que la adoración devida al Criador, la atribuian al demonio" (ibid.: 1).

Para no dejar estos argumentos sueltos, y como contestación específica al rey sobre la manera de remediar estos males, Sánchez de Aguilar propone 16 remedios (1987: 110-117). En primer lugar recomienda proceder activamente contra la idolatría, permitiendo al obispo nombrar a sus jueces eclesiásticos, quienes tomarían conocimiento de la causa y prenderían a culpados y sospechosos con el auxilio de los gobernadores y alcaldes indios de los pueblos donde se sospeche exista este delito. Los castigos propuestos son severos: "[relajar] a los dogmatizadores, y relapsos, y falsos Sacerdotes [...] al braço Real, desterrandolos desta Provincia, o condenandolos a servicios personales de Iglesias, y Monasterios, o a las fuerças de S. Juan de Ulua y La Habana" (ibid.: 110). Además recomienda el encarcelamiento perpetuo de los viejos reincidentes para que "no inficionen el resto deste rebaño" (id.).

Como segunda recomendación remarca el papel de la educación, a la cual considera "el verdadero antídoto y medicina contra la idolatria" (id.). Sugiere el establecimiento de un colegio jesuita para enseñar a los hijos de españoles, de donde saldrán sacerdotes y religiosos capaces de enseñar a los indios en su mismo idioma. En su décimo sexta recomendación vuelve sobre el tema de la educación, subrayando la conveniencia de fundar un seminario o colegio de niños hijos de principales, tal como existía en Lima. Tras aprender a leer, a escribir, a cantar, a tocar instrumentos musicales y a servir como acólitos y cantores, al volver a sus pueblos "aficionados a nuestra Religión Cristiana, y en nuestra 
lengua Española hara[n] mucho fruto en sus pueblos" (Sánchez de Aguilar 1987: 115). En el mismo sentido sugiere que se impriman libros sobre la creación del mundo y la vida de los santos en lengua indígena "pues la letura es lengua que habla alma, y por estar faltos de libros, viven sin luz [...]" (id.).

Siguen otras sugerencias, varias de las cuales parecen basarse o inspirarse en las Ordenanzas de López Medel (1551): entre ellas, impedir a los indios hacer juntas o bailes de noche (ibid.: 111); no dejarlos pasar de un pueblo a otro (id.); que no tengan altares ni cruces en sus casas, y traigan rosarios al cuello (id.); y prohibirles hacer o beber balché (id.). Insiste en que por estar tan alejados, los indios reinciden en sus antiguas prácticas, y por ello se les debe congregar para poderlos vigilar y adoctrinar. Sánchez de Aguilar también recomienda que los indios reciban el santo sacramento, añadir parroquias y curas, y que estos últimos no se muden, pues de lo contrario "[...] nunca conocen sus ovejas, ni pueden curarlas como convendría, ni saber quien es sospechoso en la idolatría" (1987: 112). Y para evitar el retorno a sus antiguas prácticas, propone sellar las cuevas y cavernas "porque en estas cuevas suelen tener sus Dioses caseros" (ibid.: 114), y nombrar un alcalde o fiscal extra para que visite a menudo las milpas, huertas, sementeras y casas de los indios (id.). Éste también habría de encargarse de la limpieza y el adorno de la iglesia, estar al tanto de la asistencia de los indios a la doctrina, visitar a los enfermos, etc.

Como hemos visto, se operaron cambios graduales entre los primeros años de la labor misional y la época en que escribe Sánchez de Aguilar. En el penúltimo de sus argumentos (1987: 40) él mismo llama la atención al rey y al Real Consejo sobre lo inadecuado de las disposiciones para los tiempos que se vivían, pues predominaba una situación diferente de la época cuando la Iglesia había emprendido su tarea misional a mediados del siglo xvı. En ese momento, la labor inmediata de los religiosos era predicar, convertir, bautizar y atraer el mayor número de almas posible para incorporarlas al seno del catolicismo. Al finalizar el siglo, dicha labor estaba prácticamente consumada.

Sin embargo, con el paso del tiempo nuevas preocupaciones se impusieron: era necesario administrar y consolidar lo ganado y evitar que se perdiera. Esta labor de consolidación concernía tanto a la Iglesia como al brazo civil. Esencialmente, los asuntos espirituales habrían de caer dentro de la órbita de la primera, y los seculares dentro de la de gobernantes y oficiales del rey. Pero la separación entre dichas esferas de acción no siempre resulta nítida, y era inevitable el surgimiento de problemas sobre la delimitación del poder de uno y otro. Si ya en el siglo xvı se habían producido querellas de esta índole, en el xvII se recrudecieron considerablemente, en especial las relativas a la aprehensión y al castigo de los indios que reincidían en sus antiguas prácticas. La idolatría se convirtió en una verdadera prueba de fuego para la supervivencia del papel preeminente de la Iglesia.

En su Informe contra idolorum cultores Sánchez de Aguilar refleja estas preocupaciones; mas aún, como abogado y defensor de la Iglesia, exige para los 
obispos, sus representantes, el derecho exclusivo de velar por el bienestar espiritual de los indios.

\section{BIBLIOGRAFÍA}

Acosta, José de

1952 De procuranda indorum salute [1588], Madrid: I.G. Magerit.

Arriaga, Joseph de

1921 La extirpación de la idolatría en Perú [1621]. Lima: Imprenta y Librería Samartí (Colección de libros y documentos referente a la historia de Perú).

Balsalobre, Gonzalo de

1987 "Relación de las idolatrías de Oaxaca" [1654], El alma encantada. Anales del Museo Nacional de México, pp. 227-269, presentación de Fernando Benítez. México: Instituto Nacional Indigenista, FCE.

Barrera Vázquez, Alfredo y Silvia Rendón

1948 El libro de los libros de Chilam Balam. México: FCE.

Barrera Vásquez, Alfredo (coord.)

1980 Diccionario Maya Cordemex. Mérida: Cordemex.

Bernard, Carmen y Serge Gruzinski

1992 De la idolatría: una arqueología de las ciencias religiosas, Diana Sánchez F. (trad.). México: FCE.

Boxer, C.R.

1978 The Church Militant and Iberian Expansion, 1440-1770. Baltimore: The Johns Hopkins University Press.

Cartas de Indias

1877 Madrid: Imprenta de Manuel G. Hernández, Ministerio de Fomento.

Cartas de religiosos de Nueva España 1539-1594

1941 Joaquín García Icazbalceta (ed.). México: Chávez Hayhoe (Nueva colección de documentos para la historia de México).

Casas, Bartolomé de las, fray

1967 Apologética Historia Sumaria. México: UNAM, Instituto de Investigaciones Históricas.

Cedulario de Puga. Provisiones, cédulas, instrucciones de su Majestad para la buena expedición de los negocios y administración de justicia y governación de esta Nueva España [1525-1563]

1878-79 México: El Sistema Postal, José María Sandoval, impresor. 
Cedulario Indiano [1596]

1945 Madrid: Ediciones Cultura Hispánica.

Chuchiak IV, John F.

2003 "It is Their Drinking That Hinders Them: Balché and the Use of Ritual Intoxicants Among the Colonial Yucatec Maya, 1550-1780", Estudios de Cultura Maya, XXIV: 137-171. México: UNAM, IIFL, Centro de Estudios Mayas.

2005 "In Servitio Dei: Fray Diego de Landa, the Franciscan Order and the Return of the Extirpation of Idolatry in the Colonial Diocese of Yucatan: 15731579", The Americas, 61 (4): 611-645. Washington D.C.: The Academy of American Franciscan History.

Cieza de León, Pedro de

1959 The Incas. Harriet de Onis (trad.). Norman: University of Oklahoma Press.

Clendinnen, Inga

1982 "Reading the Inquisitorial Record in Yucatán: Fact or Fantasy", The Americas, 38 (3): 327-345. Washington D.C.: The Academy of American Franciscan History.

1987 Ambivalent Conquests: Maya and Spaniard in Yucatán (1517-1570). Cambridge, Inglaterra: Cambridge University Press.

Códice franciscano [siglo xvı]

1941 Joaquín García Icazbalceta (ed.). México: Salvador Chavez Hayhoe (Nueva colección de documentos para la historia de México).

Códice Mendieta. Documentos franciscanos (siglos xVI y xvII)

1971 Edmundo Aviña Levy (ed.), edición facsímil. Guadalajara: E. Ariña Levy. 2 tomos.

Coloquios y doctrina cristiana con que los doce frailes de San Francisco enviados por el papa Adriano VI y por el emperador Carlos V convirtieron a los Indios de la Nueva España [1524]

1986 Edición facsimilar, introducción, paleografía, versión del náhuatl y notas de Miguel León-Portilla. México: UNAM, Fundación de Investigaciones Sociales.

Durán, Diego, fray

1995 Historia de las Indias de Nueva España e islas de tierra firme [1576-1579]. México: CONACULTA (Cien de México), 2 tomos.

Landa, Diego de, fray

1986 Relación de las cosas de Yucatán [1566]. México: Pedro Robredo.

Lizana, Bernardo de, fray

1995 Historia de Yucatán o Devocionario de Nuestra Señora de Izamal y conquista espiritual [1633]. René Acuña (ed.). México: UNAM, IIFL. 
López de Cogolludo, Diego, fray

1971 Los tres siglos de la dominación española en Yucatán o sea historia de esta provincia [1656]. Graz, Austria: Akademische Druck und Verlagsanstalt.

Lorca, Bernardino

1953 La Inquisición española. Santander: Universidad Pontificia Comillas.

Mariel de Ibáñez, Yolanda

1946 La inquisición en México durante el siglo XVI. México: Imprenta Barrie.

Mendieta, Jerónimo de, fray

1980 Historia eclesiástica indiana. México: Porrúa.

Mendieta, Rosa María y Silvia del Amo R.

1981 Plantas medicinales del Estado de Yucatán. Xalapa: Compañía Editorial Continental, Instituto Nacional de Investigaciones sobre Recursos Bióticos.

Motolinía, Toribio de Benavente, fray

1988 Historia de los indios de la Nueva España [1541]. Madrid: Alianza.

Phelan, John Liddy

1970 The Millennial Kingdom of the Franciscans in the New World. Berkeley, Los Angeles: University of California Press.

Recopilación de leyes de los reynos de las Indias

1943 Madrid: Consejo de la Hispanidad.

Relaciones histórico-geográficas de la Gobernación de Yucatán

1983 Mercedes de la Garza et al. (eds.). México: UNAM, IIFL, Centro de Estudios Mayas, 2 tomos.

Ricard, Robert

1947 La conquista espiritual de Méjico. México: Jus, Polis.

Ruiz de Alarcón, Hernando

1987 "Tratado de las supersticiones de los naturales de esta Nueva España” [1629], El alma encantada. Anales del Museo Nacional de México, pp.125-221, presentación de Fernando Benítez. México: Instituto Nacional Indigenista, FCE.

Sahagún, Bernardino de, fray

1986 Coloquios y doctrina cristiana con que los doce frailes de San Francisco enviados por el papa Adriano VI y por el emperador Carlos V convirtieron a los Indios de la Nueva España [1524]. Edición facsimilar, introducción, paleografía, versión del náhuatl y notas de Miguel León-Portilla. México: UNAM, Fundación de Investigaciones Sociales.

1981 Historia general de las cosas de Nueva España [ca. 1579] México: Porrúa, 4 tomos. 
Sánchez de Aguilar, Pedro

1987 “Informe contra idolorum cultores del Obispado de Yucatán” [1639], El alma encantada. Anales del Museo Nacional de México, pp. 15-122, presentación de Fernando Benítez. México: Instituto Nacional Indigenista, FCE.

Scholes, France V. y Eleanor B. Adams

1938 Don Diego Quijada, Alcalde de Yucatán [1561-1565]. México: Antigua Librería Robredo de José Porrúa e Hijos.

Scholes, France V. et al.

1936-38 Documentos para la historia de Yucatán, $1^{\text {a }}$ y $2^{\text {a }}$ serie. Mérida: Compañía Tipográfica Yucateca.

Serna, Jacinto de la

1987 "Manual de ministros de Indias" [1656], El alma encantada. Anales del Museo Nacional de México, pp. 263-480. México: Instituto Nacional Indigenista, FCE.

Tavárez, David Eduardo

1999 "La idolatría letrada: un análisis comparativo de textos clandestinos rituales y devocionales en comunidades nahuas y zapotecas, 1613-1654", Historia mexicana, XLIX (2), octubre-diciembre: 197-252. México: El Colegio de México.

Torquemada, Juan de, fray

1975-79 Monarquía indiana [1615]. México: UNAM, IIH, 6 tomos.

Torture Instruments/Instrumentos de tortura

1996 Guía bilingüe de la exposición. México: Academia Mexicana de Derechos Humanos.

Tozzer, Alfred M.

1977 A Maya Grammar. Nueva York: Dover Publications.

Yucatán en el tiempo: enciclopedia alfabética

1998 Mérida: CARES, 6 tomos. 